\title{
Fatty acid composition and cholesterol content of beef and chicken meat in Southern Brazil
}

\author{
Jussara Carnevale de Almeida ${ }^{1}$, Magda Susana Perassoloํ, Joíza Lins Camargo² \\ Neura Bragagnolo ${ }^{3}$, Jorge Luis Gross ${ }^{1 *}$
}

${ }^{1}$ Serviço de Endocrinologia do Hospital de Clínicas de Porto Alegre, Universidade Federal do Rio Grande do Sul

${ }^{2}$ Serviço de Patologia Clínica do Hospital de Clínicas de Porto Alegre, Universidade Federal do Rio Grande do Sul

${ }^{3}$ Departamento de Ciências de Alimentos, Faculdade de Engenharia de Alimentos, Universidade Estadual de Campinas

*Correspondence:

J. L. Gross

Rua Ramiro Barcelos 2350, Prédio 12, $4^{\circ}$ andar

90035-003 - Porto Alegre, RS - Brasil

E-mail: jorgegross@terra.com.br
The aim of the present study was to analyze the fatty acid composition and cholesterol content of the beef and chicken meat most often consumed by a population of type 2 diabetic patients in Southern Brazil: for beef, semimembranosus and biceps femoris; and for chicken, drumstick and thigh. The moisture content (gravimetrically), protein content (Kjeldahl procedure), cholesterol content (HPLC or enzymatic methods), lipid content (gravimetric method) and fatty acid composition (gas chromatography) were analyzed in three different brands of these raw cuts in duplicate. The results were compared with data extracted from the United States Department of Agriculture (USDA) Handbook and Brazilian tables (TACO-UNICAMP and TBCAUSP 4.1). Chicken meat had a lower proportion of saturated $(36.4 \pm 3.6 \%$; $P<0.001)$ and a higher proportion of polyunsaturated fatty acids $(21.3 \pm 3.5 \%$; $P<0.0001)$ than beef (53.3 \pm 2.12 and $3.0 \pm 0.5 \%)$. Long chain omega-3 polyunsaturated fatty acids (PUFA) eicosapentaenoic and docosahexaenoic were observed only in dark chicken meat (23 \pm 3 and $14 \pm 1 \mathrm{mg} / 100 \mathrm{~g}$, respectively) and were found in less than $0.1 \mathrm{mg} / 100 \mathrm{~g}$ in beef cuts. The amount of gamma and alpha linolenic acids in biceps femoris (39/22 $\mathrm{mg} / 100 \mathrm{~g})$ was higher than in dark chicken meat (1/25 mg/100 g). A discrepancy was observed between the composition of the experimental meats and those reported in the USDA Handbook, mainly for beef. Total lipid content as well as PUFA and monounsaturated fatty acid (MUFA) levels were lower than the values reported in the USDA Handbook (26.5, 49 and 25\% difference than USDA values, respectively) for beef. Chicken meat presents a more favorable fatty acid profile regarding serum cholesterol levels than beef cuts. Furthermore, the discrepancies observed between our experimental data and the USDA Handbook suggest that it is important to construct regional food composition tables.
Uniterms

- Chicken

- Fatty acids

- Polyunsaturated

- Saturated

- Linolenic

- Beef 


\section{INTRODUCTION}

Food composition data are important to a spectrum of users ranging from international organizations and private individuals: to food assistance programs, epidemiologists correlate patterns of disease with dietary components and nutritional assessment of individual intake and dietetic counseling (Rand, 1991). Each of these activities requires accurate data on the composition of foods, and requires that these data be in a form that permits easy access, intelligent manipulation, and confident usage.

The total fat intake, saturated fat (SFA), monounsaturated (MUFA), or polyunsaturated fat (PUFA) intake are independent risk factors for prospective all-cause, cardiovascular and cancer mortality (Leosdottir, 2005). Most current dietary guidelines (American Diabetic Association 2005, OMS 2003) encourage limiting relative fat intake to $<30 \%$ of total daily energy, with SFA and trans fatty acids contributing no more than $10 \%$. The meats are important sources of fat in the typical diet in Southern Brazil. Many consumers believe that red meat is unhealthful, because is high in SFA and cholesterol (Keee, 2000). In fact, it has been recently demonstrated that replacement of red meat with chicken is associated with a significant decrease in apolipoprotein B and total cholesterol levels in microalbuminuric type 2 diabetic patients (Gross et al., 2002). This effect is probably related to the higher PUFA content of chicken meat in comparison to beef.

The beneficial effects of PUFA depend on the ratio of the fatty acid omega $6(n-6)$ to omega $3(n-3)$; it is generally accepted that the ideal proportion of $n-6$ to $n-3$ is around 4:1. However, the current ratio in the usual Western diet ranges from 20 to 30:1, which may favor a prothrombotic and proaggregatory state (Schaefer et al., 2002). Therefore, knowledge concerning the exact fatty acid composition of the meat consumed by different populations is extremely important.

The information about the fatty acid composition of foods are scarce and specially limited to foreign tables (Menezes, 2002). The fatty acid content of different meats might be influenced by a wide variety of factors, including animal breed, external and internal fat levels, climate, and breeding, feeding and rearing conditions (Bragagnolo, 1997). These factors may vary according to the region where animals are created and according to cultural practices.

As far as we know every few information were available in Latin America literature regarding the food composition tables, national originary projects (Food Composition Integrated Project: TBCAUSP 4.1 and TACO-UNICAMP) to compile existing data and also to analyses how food items are being developed, based on lo- cal priorities indicated by nutrition surveys. Collaborative studies on analytical techniques were also undertaken.

Therefore, the aim of the present study was to analyze the fatty acid composition and cholesterol content of the beef and chicken cuts most often consumed by type 2 diabetic patients in Porto Alegre, a major city in Southern Brazil.

\section{MATERIAL AND METHODS}

\section{Meats Consumed By Type 2 Diabetic Patients}

The meats most often consumed by the diabetic patients at the endocrinology outpatient clinic at Hospital de Clínicas de Porto Alegre, RS, Brazil were determined as previously described, based on interviews and training in the technique of 3-day weighed diet records (Moulin et al., 1998). A sample of type 2 diabetic patients were selected. Only patients with a concordance of less than $70 \%$ between the recorded protein intake and the values estimated by 24 -h urinary nitrogen excretion were included. As a result seventy-four patients were selected for the present study.

The average meat intake per person was $167 \pm 84 \mathrm{~g}$ per day. Beef accounted for $58 \%$ of the weekly consumption of meat; chicken accounted for $30 \%$; fish for $6 \%$; pork for $5 \%$; and mutton for $1 \%$.

The main beef cuts consumed were tip round (semimembranosus and biceps femoris muscle 35\%), ribs $(25 \%)$, choice meat $(20 \%)$, quality meat $(13 \%)$, sausage, bologna and beef ham (7\%). Dark chicken meat (thigh and drumstick) was the most consumed cut (64\%), followed by breast meat (29\%), chicken sausage and bologna (5\%), wings and back (2\%).

Based on the meat intake in this pilot population, we chose to analyze the fatty acid composition and cholesterol content of semimembranosus and biceps femoris beef cuts and chicken thigh and drumstick.

\section{Preparation of Samples}

Three different brands of chicken meat, and beef from three different sources were purchased at a supermarket. Each sample was hand-boned (chicken) and dissected from the fat surface, and the lean part was then finely minced. Each raw sample was analyzed in duplicate. The cholesterol analysis was conducted in triplicate.

\section{Moisture and protein analyses}

Dry matter was obtained from each piece of meat by drying samples in an oven for $20 \mathrm{~h}$ at $105^{\circ} \mathrm{C}$ (method 950.46 described in Cuniff, 1997). The protein content was 
calculated as nitrogen amount multiplied by 0.625 per $100 \mathrm{~g}$ of meat. The nitrogen content was determined by the Kjeldahl procedure (method 928.08 described in Cuniff, 1997).

\section{Cholesterol Analysis}

Step 1 - Saponification: About $2 \mathrm{~g}$ of each sample were saponified according to a modified version of the method described by Stewart et al. (1992), with $4 \mathrm{~mL}$ of $50 \%$ potassium hydroxide and $6 \mathrm{~mL}$ of $95 \%$ ethanol absolute heated for complete solubilization at $40{ }^{\circ} \mathrm{C}$, and then heated for $10 \mathrm{~min}$ at $60{ }^{\circ} \mathrm{C}$. After this, $5 \mathrm{~mL}$ of water were added and the sample were cooled. The nonsaponifiable fraction was extracted three times using $10 \mathrm{~mL}$ of hexane. Aliquots of hexane extracts $(3 \mathrm{~mL})$ were dried under a nitrogen flow.

Step 2 - Cholesterol Measurement: After saponification, samples were analyzed by high-performance liquid chromatography (HPLC) or enzymatic methods.

HPLC: The extract was dissolved again in $3 \mathrm{~mL}$ of acetonitrile-isopropanol solution $(70: 30, \mathrm{v} / \mathrm{v})$ and $1 \mathrm{~mL}$ was injected into HPLC (Bragagnolo et al., 2001). The HPLC apparatus consisted of a SHIMADZU ${ }^{\circledR}$ system including a ternary solvent delivery system (LAD 10); a Rheodyne $20 \mathrm{~mL}$ loop injector with column temperature of $30^{\circ} \mathrm{C}$; ultraviolet detector; and software (CLAS-VP 10) for data processing. A Lichrospher 5RP18 $150 \times 4.6 \mathrm{~mm}$ analytical column was employed, including a holder with guard column (Chrompack ${ }^{\circledR}$, The Netherlands). The mobile phase (flow rate $=1 \mathrm{~mL} / \mathrm{min}$ ) consisted of acetonitrile and isopropanol $(70: 30, \mathrm{v} / \mathrm{v})$. The resulting chromatograms were processed at $210 \mathrm{~nm}$.

Cholesterol identification was performed by cochromatography and by comparing sample retention times with standard retention times (Sigma and Polyscience, U.S.A. ${ }^{\circledR}$ C8667). Quantification for each sample was achieved by internal standardization $(0.504 \mathrm{mg}$ of 6 ketocholestanol, Sigma and Polyscience, U.S.A. ${ }^{\circledR}$ K1250) after saponification. The response factors were calculated daily during the sample period.

Enzymatic method: The extract was diluted in $0.2 \mathrm{~mL}$ of isopropyl alcohol and analyzed with an enzymatic kit (Merck ${ }^{\circledR}$ Diagnostica, Darmstadt, Germany) adapted to the Cobas Mira Roche ${ }^{\circledR}$ auto-analyzer.

\section{Fatty Acid Composition}

Step 1 - Lipid Extraction: The lipids were extracted according to Folch et al.(1957) with a chloroformmethanol mixture $(2: 1$, by $200 \mathrm{~mL})(12)$. Four $10 \mathrm{~mL}$ aliquots were saved for the next steps.
Step 2 - Total Lipid Determination: The total lipid content was determined gravimetrically on an analytical scale (Marte ${ }^{\circledR}$, precision of $0.001 \mathrm{~g}$ ).

Step 3 - Fatty Acid Identification: Aliquots of the lipid extract were esterified with $\mathrm{BF}_{3}$-methanol (Joseph et al., 1992). The fatty acid composition of each aliquot was determined by gas chromatography on a $60 \mathrm{~m}$ fused capillary column with an internal diameter of $0.20 \mathrm{~mm}$ (CP Sil 88). The analysis was performed on a HewlettPackard $6890^{\circledR}$ gas chromatograph equipped with a flame ionization detector. Helium was used as carrier gas and nitrogen as make-up gas. The injection port temperature was $200{ }^{\circ} \mathrm{C}$ and the detector temperature was $250{ }^{\circ} \mathrm{C}$. Oven temperature was ramped to $150{ }^{\circ} \mathrm{C}$ for 3 min and increased to $160{ }^{\circ} \mathrm{C}$ at $1.5{ }^{\circ} \mathrm{C} / \mathrm{min}$; it was then held at $160{ }^{\circ} \mathrm{C}$ for $3 \mathrm{~min}$, increased to $190{ }^{\circ} \mathrm{C}$ at $1.5{ }^{\circ} \mathrm{C} /$ min, and held at $190{ }^{\circ} \mathrm{C}$ for $1 \mathrm{~min}$. Finally, temperature was increased to $220{ }^{\circ} \mathrm{C}$ at $1{ }^{\circ} \mathrm{C} / \mathrm{min}$.

A Hewlett Packard computing integrator calculated retention times and peak area percentages. Fatty acids were identified by comparing sample retention times with standard retention times (36 saturated, monounsaturated and polyunsaturated fatty acid standards, Sigma and Polyscience, U.S.A. ${ }^{\circledR}$ ). Quantification was carried out by normalization and transformation of the area percentage to $\mathrm{mg}$ per $100 \mathrm{~g}$ of edible portion, using the lipid conversion factor of Holland (1994).

\section{Statistical Analysis}

Data were analyzed with the following parametric tests: ANOVA and one-sample $t$-test for comparison between experimental values and those published in the USDA Handbook SR-14 (USDA, 2001). Non-parametric data were logarithm transformed before statistical analysis. Values were expressed as means \pm standard deviation (SD). Significance was defined at $\mathrm{P}<0.05$. The SPSS software (Chicago, IL) was used for all analyses.

\section{RESULTS}

\section{Chemical Composition of Raw Meats}

Moisture, protein, fat and cholesterol content of raw meats are described in Table I. Moisture was higher in dark chicken meat than in beef. The semimembranosus cut presented higher moisture content than the biceps femoris cut. In general, the moisture of experimental meats was higher than that reported in the USDA Handbook: 3.2\% higher for semimembranosus $(74.48 \pm 1.08$ vs. $72.20 \mathrm{~g} / 100 \mathrm{~g}), 10.4 \%$ for biceps femoris $(72.48 \pm 1.57 \mathrm{vs} .64 .92 \mathrm{~g} / 100 \mathrm{~g})$ and $2.0 \%$ 
TABLE I - Chemical Composition (per $100 \mathrm{~g}$ ) of Raw Chicken and Beef

\begin{tabular}{|c|c|c|c|c|}
\hline & \multicolumn{2}{|c|}{ Beef cuts } & \multirow[t]{2}{*}{ Dark chicken meat $^{a}$} & \multirow[t]{2}{*}{ Anova $\mathrm{P}^{b}$} \\
\hline & Semimembranosus & Biceps femoris & & \\
\hline Moisture $(\mathrm{g})^{c}$ & $74.48 \pm 1.08$ & $72.48 \pm 1.57$ & $77.49 \pm 1.04$ & $<0.001^{d}$ \\
\hline Protein $(\mathrm{g})^{c}$ & $21.17 \pm 0.16$ & $20.97 \pm 0.04$ & $18.83 \pm 0.09$ & $<0.001^{e}$ \\
\hline Fat $(\mathrm{g})^{c}$ & $3.08 \pm 0.07$ & $8.75 \pm 1.12$ & $4.08 \pm 0.60$ & $<0.001^{f}$ \\
\hline Cholesterol $(\mathrm{mg})^{g}$ & $51.97 \pm 1.40$ & $63.02 \pm 3.62$ & $80.30 \pm 2.83$ & $<0.001^{d}$ \\
\hline
\end{tabular}

${ }^{a}$ Data concerning drumstick and thigh were grouped (40:60 proportion); ${ }^{b}$ ANOVA was used for normal-distribution values and logarithm-transformed data for non-normal-distribution values; ${ }^{c}$ Data presented as mean $\pm \mathrm{SD}$ of three brands (A-C), in duplicate, $\mathrm{n}=3 ;{ }^{d}$ All meats were statistically different (Student-Newman-Keuls) from each other $(\mathrm{P}<0.001)$; ${ }^{e}$ Dark chicken meat was statistically different (Student-Newman-Keuls) as compared to beef cuts $(\mathrm{P}<0.001){ }^{f}$ Biceps femoris was statistically different (Student-Newman-Keuls) as compared to Semimembranosus and dark chicken meat $(\mathrm{P}<0.001) ;{ }^{g}$ Data presented as mean $\pm \mathrm{SD}$ of three brands $(\mathrm{A}-\mathrm{C})$, in triplicate, $\mathrm{n}=3$.

for dark chicken meat $(77.49 \pm 1.04$ vs $75.99 \mathrm{~g} / 100 \mathrm{~g})$ $(\mathrm{P}<0.01)$.

The protein content of beef was higher than that of dark chicken meat. The protein content of biceps femoris $(20.97 \pm 0.04 \mathrm{~g} / 100 \mathrm{~g})$ was $8.6 \%$ higher than the value listed in the USDA Handbook (19.31 g/100g; $\mathrm{P}=0.012)$. On the other hand, the protein content of dark chicken meat $(18.83 \pm 0.09 \mathrm{~g} / 100 \mathrm{~g})$ was $6.2 \%$ lower than USDA values $(20.08 \mathrm{~g} / 100 \mathrm{~g} ; \mathrm{P}=0.0001)$. The protein content of semimembranosus was similar to USDA values $(21.17 \pm$ 0.16 vs. $21.11 \mathrm{~g} / 100 \mathrm{~g}$ ).

The lipid content of biceps femoris was higher than that of semimembranosus and dark chicken meat. On the other hand, dark chicken meat presented higher lipid values than semimembranosus. The observed lipid content in both beef cuts were $26.5 \%$ lower as compared with the values listed in the USDA Handbook, i.e., $3.08 \pm 0.07$ vs. $3.80 \mathrm{~g} / 100 \mathrm{~g}$ for semimembranosus $(\mathrm{P}<0.003)$ and $8.75 \pm 1.12$ vs. $13.19 \mathrm{~g} / 100 \mathrm{~g}(\mathrm{P}<0.021)$ for biceps femoris. No difference was observed concerning the lipid content of chicken dark meat $(4.08 \pm 0.60$ for experimental samples vs. $4.31 \mathrm{~g} / 100 \mathrm{~g}$ in the USDA Handbook).

Cholesterol levels measured by the enzymatic method were higher than those measured by the HPLC method: $17 \%$ in semimembranosus $(60.63 \pm 2.33 \mathrm{vs}$. $51.97 \pm 1.40 \mathrm{mg} / 100 \mathrm{~g}), 17.5 \%$ in chicken drumsticks $(104.31 \pm 6.34$ vs. $86.09 \pm 3.34 \mathrm{~g} / 100 \mathrm{~g})$ and $29.3 \%$ in chicken thighs ( $98.82 \pm 7.85$ vs. $76.44 \pm 2.49 \mathrm{mg} / 100 \mathrm{~g})$; $\mathrm{P}<0.03$. No difference was observed in the cholesterol values obtained by the two methods for biceps femoris $(63.02 \pm 3.62$ vs. $63.44 \pm 3.75 \mathrm{mg} / 100 \mathrm{~g})$ (Figure 1). The variability of cholesterol values was higher with the enzymatic method than with the HPLC method. The coefficients of variation for cholesterol measurements were below $4 \%$ for HPLC and below $6 \%$ for the enzymatic method. This discrepancy was more evident when chicken meat was analyzed (3.6 vs. $7.0 \%$ ).

Regarding the cholesterol content as measured by HPLC, it was observed that dark chicken meat presented higher cholesterol levels than beef cuts. The cholesterol content of biceps femoris was higher than that of semimembranosus. When the experimental data were compared with USDA information, the observed cholesterol content of semimembranosus was $14 \%$ lower than USDA values $(51.97 \pm 1.40 v s .60 \mathrm{mg} / 100 \mathrm{~g}$; $\mathrm{P}=0.01)$. However, the cholesterol content of dark chicken meat and biceps femoris was similar to USDA values: $80.30 \pm 2.83 v s .80 \mathrm{mg} / 100 \mathrm{~g}$ for dark chicken meat and $63.02 \pm 3.62 \mathrm{vs} .65 \mathrm{mg} / 100 \mathrm{~g}$ for biceps femoris.

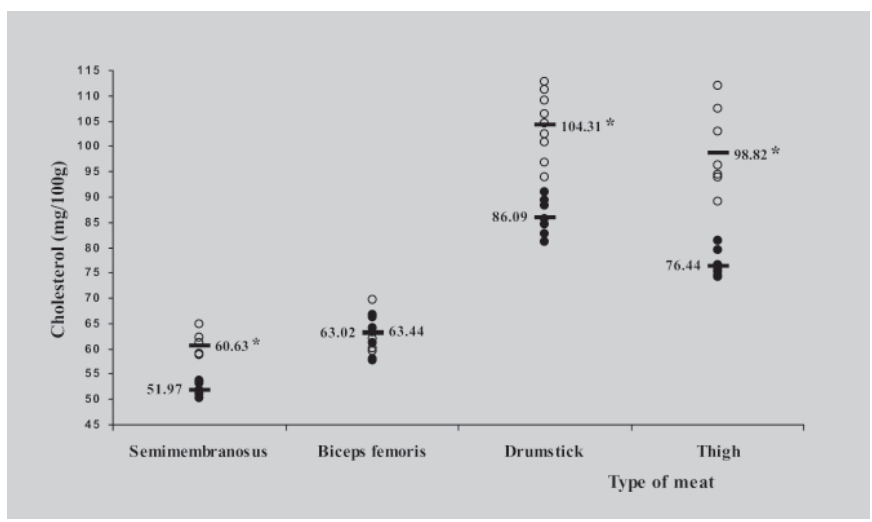

FIGURE 1 - Comparison between two cholesterol analysis methods (mg per $100 \mathrm{~g}$ ) in raw experimental foods: results obtained with enzymatic method (o) and HPLC method (·). Mean values presented as and significance calculated by logarithm-transformed data. Independent $t$ test was used. $*=\mathrm{P}<0.05$ 


\section{Fatty Acid Composition of Raw Meats}

The fatty acid values obtained in the experimental meats are described in Table II. Total saturated fatty acid (SFA) contents were approximetely three times higher in biceps femoris than in semimembranosus and dark chicken meat. This was particularly evident in relation to palmitic acid (16:0). Myristic acid (14:0) and stearic acid (18:0) values were also higher in biceps femoris as compared to semimembranosus and dark chicken meat, and higher in semimembranosus than in dark chicken meat. The levels of monounsaturated fatty acids (MUFA), palmitoleic acid (16:1n-7) and oleic acid (18:1n-9) were higher in biceps femoris than in semimembranosus and dark chicken meat, and also in dark chicken meat as compared to semimembranosus. Total PUFA, n-3 PUFA, n-6 PUFA, and linoleic acid (18:2n-6) contents were higher in dark chicken meat as compared to beef. The total PUFA content was higher in biceps femoris as compared to semimembranosus. The very long chain n-3 PUFA EPA (22:5n-3) and DHA (22:6n-3), were observed only in dark chicken meat ( $23 \pm 3$ and $14 \pm 1 \mathrm{mg} / 100 \mathrm{~g}$, respectively). The amount of these fatty acids in beef cuts was not presented (less than
$0.1 \mathrm{mg} / 100 \mathrm{~g})$. The proportion of gamma (18:3n-6) and alpha linolenic (18:3n-3) fatty acids in the biceps femoris cut $(39 / 22 \mathrm{mg} / 100 \mathrm{~g})$ was higher than in dark chicken meat $(1 / 25 \mathrm{mg} / 100 \mathrm{~g})$ (Table II).

Due to the difference in lipid content between beef cuts, we chose to compare the two experimental cuts in terms of the proportion of fatty acids in relation to the lipid content rather than the proportion of fatty acid in $100 \mathrm{~g}$ of meat (Figure 2). The observed proportion of MUFA was similar in the beef cuts and chicken meat. The SFA and PUFA proportions were similar in both beef cuts, but higher $(\mathrm{P}<0.001)$ and lower $(\mathrm{P}<0.0001)$ than in dark chicken meat, respectively.

The fatty acid contents of the experimental meats were compared with USDA values. The SFA content of biceps femoris was $12 \%$ lower (4610 \pm 198 vs. $5240 \mathrm{mg} /$ $100 \mathrm{~g} ; \mathrm{P}=0.041$ ) than the USDA values; in semimembranosus the values were $21 \%$ higher $(1555 \pm 61$ vs. 1290 $\mathrm{mg} / 100 \mathrm{~g} ; \mathrm{P}=0.013)$; and in dark chicken meat the content was similar $(1428 \pm 124$ vs. $1100 \mathrm{mg} / 100 \mathrm{~g})$. The MUFA content of beef cuts was $25 \%$ lower, and of dark chicken meat $23 \%$ higher as compared to USDA values: biceps femoris (3649 \pm 87 vs. $5660 \mathrm{mg} / 100 \mathrm{~g}$; $\mathrm{P}=0.039$ ),

TABLE II - Fatty Acid Composition (mg/100 g) of Raw Chicken and Beef ${ }^{a}$

\begin{tabular}{lcccc}
\hline Composition & \multicolumn{2}{c}{ Beef cuts } & Dark chicken & Anova P $^{b}$ \\
\cline { 2 - 3 } & Semimembranosus & Biceps femoris & meat $^{a}$ & \\
\hline Myristic acid (14:0) & $99 \pm 9$ & $356 \pm 11$ & $29 \pm 3$ & $<0.001^{d}$ \\
Palmitic acid (16:0) & $958 \pm 61$ & $2804 \pm 198$ & $1097 \pm 124$ & $<0.001^{e}$ \\
Stearic acid (18:0) & $498 \pm 46$ & $1450 \pm 119$ & $302 \pm 22$ & $<0.001^{d}$ \\
Total saturated fatty acids & $1555 \pm 116$ & $4610 \pm 328$ & $1428 \pm 124$ & $<0.001^{e}$ \\
Palmitoleic acid (16:1n-7) & $207 \pm 173$ & $639 \pm 87$ & $298 \pm 56$ & $<0.010^{e}$ \\
Oleic acid (18:1n-9) & $1108 \pm 118$ & $3010 \pm 80$ & $1366 \pm 77$ & $<0.001^{d}$ \\
n-9 monounsaturated & $1108 \pm 118$ & $3010 \pm 80$ & $1366 \pm 77$ & $<0.001^{d}$ \\
Total monounsaturated fatty acid & $1315 \pm 173$ & $3649 \pm 87$ & $1664 \pm 77$ & $<0.001^{d}$ \\
Linoleic acid (18:2n-6) & $35 \pm 24$ & $183 \pm 24$ & $728 \pm 94$ & $<0.001^{f}$ \\
Gamma-linolenic (18:3n-6) & 1 & $39 \pm 10$ & 1 & $<0.001^{e}$ \\
$\alpha$-Linolenic acid (18:3n-3) & $32 \pm 10$ & $22 \pm 5$ & $25 \pm 4$ & 0.263 \\
Arachidonic acid (20:4n-6) & $21 \pm 5$ & $15 \pm 1$ & $46 \pm 3$ & 0.110 \\
Eicosapentaenoic acid (EPA, 22:5n-3) & 0.1 & 0.1 & $23 \pm 3$ & $0.001^{f}$ \\
Docosahexaenoic acid(DHA, 22:6n-3) & 0.1 & 0.1 & $14 \pm 1$ & $0.014^{f}$ \\
n-3 polyunsaturated fatty acid & $32 \pm 10$ & $22 \pm 5$ & $62 \pm 4$ & $0.001^{f}$ \\
n-6 polyunsaturated fatty acid & $57 \pm 24$ & $237 \pm 24$ & $775 \pm 94$ & $<0.001^{f}$ \\
Total polyunsaturated fatty acid & $89 \pm 24$ & $259 \pm 24$ & $837 \pm 94$ & $<0.001^{f}$ \\
\hline
\end{tabular}

${ }^{a}$ Data presented as mean $\pm \mathrm{SD} ;{ }^{b}$ Data obtained from drumstick and thigh were grouped (40:60 proportion); ${ }^{c}$ ANOVA was used for normal-distribution values and logarithm-transformed data for non-normal-distribution values; ${ }^{d}$ All meats were statistically different (Student-Newman-Keuls) from each other $(\mathrm{P}<0.001) ;{ }^{e}$ Biceps femoris was statistically different (Student-Newman-Keuls) as compared to Semimembranosus and dark chicken meat $(\mathrm{P}<0.001)$; ${ }^{\circ}$ Dark chicken meat was statistically different (Student-Newman-Keuls) as compared to beef cuts $(\mathrm{P}<0.001)$. 


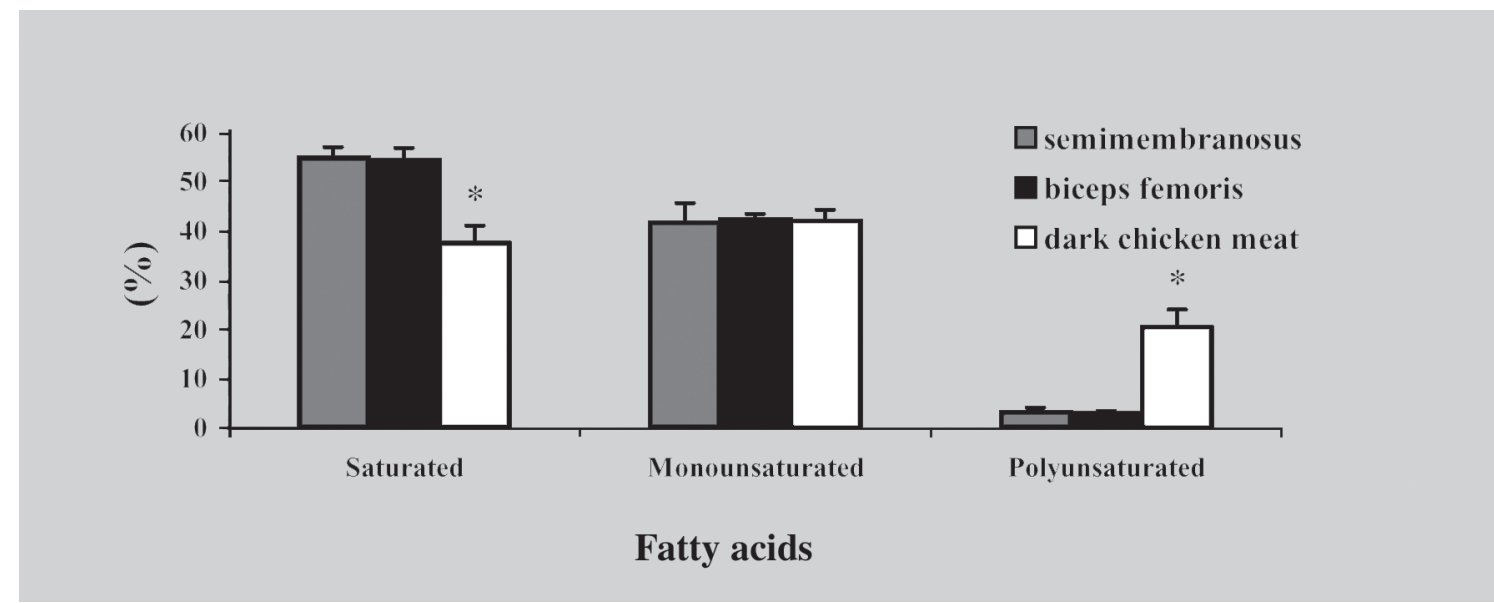

FIGURE 2- Proportion of fatty acid (\%) in different experimental meats. Values expressed as mean $\pm \mathrm{SD}$ and significance calculated by logarithm-transformed data. ANOVA was used. * $=\mathrm{P}<0.01$ (Student-Newman-Keuls).

semimembranosus $(1315 \pm 173$ vs. $1550 \mathrm{mg} / 100 \mathrm{~g}$; $\mathrm{P}=0.001)$ and dark chicken meat, $(1664 \pm 77$ vs. 1340 $\mathrm{mg} / 100 \mathrm{~g} ; \mathrm{P}=0.022)$. The PUFA content of beef cuts was observed to be $49 \%$ lower than USDA values, but the values obtained for dark chicken meat were similar to those of the USDA Handbook: biceps femoris $(259 \pm 24$ vs. $520 \mathrm{mg} / 100 \mathrm{~g} ; \mathrm{P}=0.003)$, semimembranosus $(89 \pm 24$ vs. $180 \mathrm{mg} / 100 \mathrm{~g} ; \mathrm{P}=0.024)$ and dark chicken meat ( 837 \pm 94 vs. $1070 \mathrm{mg} / 100 \mathrm{~g}$ ).

\section{DISCUSSION}

The present experimental data indicate that beef cuts in Porto Alegre, Southern Brazil, presented higher proportions of SFA and lower proportions of PUFA (principally of the n-3 family) than dark chicken meat.

The proportion of fatty acids described in this study is similar to that described for raw chicken leg in Australia (Badiani, 2002) and Venezuela (Hutchion, 1987). However, the total lipid content of Australian chicken was higher $(5.5 \mathrm{~g} / 100 \mathrm{~g})$ than that reported by us; in addition, no long chain PUFA n-3 was observed in Australia (Hutchion, 1987). No fatty acid content of raw chicken meat was described in brazilian tables of food composition (BRASILFOODS, 2005; TACO-NEPA, 2004).

Although the cholesterol content of chicken meat is higher than that of beef, the higher PUFA and lower SFA proportions in chicken may explain the $18 \%$ reduction in serum total cholesterol levels observed in a previous study when microalbuminuric type 2 diabetic patients replaced red meat by chicken (Gross et al., 2002). This supports the notion that the type of dietary fatty acid, rather than the level of dietary cholesterol, is the most potent regulator of serum cholesterol levels (Schaefer, 2002). It is known that dietary cholesterol have an inverse effect in endogenous cholesterol synthesis (Jones, 1997) and higher SFA intake decrease LDL receptor-mediated catabolism (Schaefer, 2002).

Comparing our results with the information listed in the USDA Handbook we observed a few discrepancies, mainly for beef. Total lipid content, as well as PUFA and MUFA proportions, were lower (26.5, 49 and $25 \%$, respectively) in our beef samples than in the USDA Handbook. The cholesterol content of the semimembranosus cut was 14\% lower than the reported USDA Handbook values. These discrepancies could be attributed to seasonal effects and/or feeding conditions.

Also, it is assumed that the meat cuts described in the USDA Handbook are retail meat cuts. WahrmundWyle et al. (2000) reported that the lipid content for separable lean from most cuts was lower that currently reported in the USDA Handbook. This was attributed to a health-conscious trend of the public and to a lower marbling content. Furthermore, the muscle groups associated with retail cuts vary depending on the region or country where they are produced (Savell et al., 2000). The gluteobiceps muscle contained the highest amounts of fatty acids including PUFA, and the longissimus dorsi the lowest amounts of PUFA in beef (Enser et al., 1998). The lipid content of semimembranosus was twice than values described in the Tabela Brasileira de Composição de Alimentos (TACO-NEPA, 2004) for semimembranosus, but no differences was observed concerning the lipid content of biceps femoris.

As regards chicken meat, the 23\% higher MUFA content observed by us in relation to USDA values could be the result of marked advances in hen farming, 
especially in breeding and feeding practices. Genetic improvement, together with changes in feeding techniques, have reduced the time required to achieve slaughter weight from 120 days in the 1970s to 45 days at present (Albino, Neme, 1998). The Brazilian tables of food composition (BRASILFOODS, 2005; TACONEPA, 2004) did not describe values of dark raw chicken meat without skin. When the experimental data were compared with Brazilian information, the observed cholesterol content of semimembranosus was $15.5 \%$ lower than TACO-NEPA (2004) but similar than BRASILFOODS (2005) values, the cholesterol content of biceps femoris was $28.6 \%$ lower than values described in BRASILFOODS (2005) and 33.3\% higher than TACO-NEPA (2004) values.

Other authors have also observed discrepancies between food composition tables and the fatty acid contents of common foods: Taber et al. (1998) reported that the levels of arachidonic acid were twice as high in raw and cooked beef, chicken breast and turkey breast as compared with the USDA Handbook SR-8. In contrast, arachidonic acid and n-3 family fatty acid contents in tuna were almost half the table values. This was attributed to the differences in the analysis and conversion of $\mathrm{w} / \mathrm{w}$ values to $\mathrm{mg}$ per $100 \mathrm{~g}$ and to cattle breed and age. The lipid content of separable lean in most cuts in a Texas study (Vizcarrondo et al., 1988) was lower than that currently reported in the USDA Handbook. In Brazil, cattle are slaughtered with $5 \mathrm{~mm}$ of level fat, similarly to Texas.

When we compared the methods used to measure cholesterol content, we observed that the enzymatic method overestimated this value in both experimental meats. Karkalas et al. (1982) have observed a very good agreement between the enzymatic and gas-liquid chromatography (GLC) methods when analyzing the cholesterol content of poultry and cheese. Bohac et al. (1988) have also reported a good agreement between the colorimetric and GLC methods in pork and beef. In the present study, the difference in the results obtained with the two methods could have been caused by interfering substances (Rifai, 1997). In any case, our results showed that the HPLC method is a better choice for measuring the cholesterol content of meats.

In conclusion, in this study chicken meat presented a more favorable fatty acid profile in terms of serum cholesterol than beef cuts. Furthermore, the discrepancies observed between our experimental data and USDA values suggest that it is important to construct regional tables of food composition, especially concerning lipid and fatty acid content.

\section{ACKNOWLEDGMENTS}

This study was partially supported by Projeto de Núcleos de Excelência do Ministério de Ciência e Tecnologia (PRONEX) and scholarships from Coordenação de Aperfeiçoamento de Pessoal de Nível Superior (CAPES).

\section{RESUMO}

\section{Composição de ácidos graxos e conteúdo de colesterol de cortes de carne de gado e frango do Sul do Brasil}

O objetivo do presente estudo foi analisar a composição de ácidos graxos e conteúdo de colesterol de cortes de carne de gado e frango mais consumidos pela população de pacientes com diabete melito tipo 2 atendidos no Sul do Brasil: para gado, cortes de semimembranosus $e$ biceps femoris; e para frango, coxa e sobrecoxa. Os conteúdos de umidade (gravimetria), proteina (procedimento de Kjeldahl), colesterol (HPLC ou método enzimático), lipídeos (método gravimétrico) e composição de ácidos graxos (cromatografia gasosa) foram analisados em amostras cruas de três diferentes procedências de cada corte em duplicata. Os resultados foram comparados com dados extraídos da tabela de composição de alimentos disponibilizada pelo Departamento de Agricultura dos Estados Unidos (USDA) e tabelas brasileiras (TACO-UNICAMP, TBCAUSP 4.1). Carne de frango possui menor proporção de ácidos graxos saturados $(36,4 \pm 3,6 \%$; $P<0,001)$ e maior proporção de ácidos graxos poliinsaturados $(21,3 \pm 3,5 \% ; P<0,0001)$ do que a carne de gado $(53,3 \pm 2,12$ e 3,0 $\pm 0,5 \%$ ). Ácidos graxos poliinsaturados (PUFA) ômega 3 de cadeia longa eicosapentaenóico e docosaexaenóico foram observados somente na carne escura do frango (23 \pm 3 e $14 \pm 1 \mathrm{mg} / 100 \mathrm{~g}$, respectivamente) e foram encontrados em quantidades não significativas (menos de $0,1 \mathrm{mg} / 100 \mathrm{~g}$ ) nos cortes de carne de gado. A quantidade de ácidos graxos gama e alfa-linolênicos no biceps femoris (39/22 mg/100 g) foi maior do que na carne escura de frango $(1 / 25 \mathrm{mg} / 100 \mathrm{~g})$. Diferenças foram observadas entre a composição das carnes experimentais e as descritas pela tabela americana, principalmente para o gado. O conteúdo total de lipídeos, assim como de PUFA e monoinsaturados (MUFA), foi menor do que os descritos pela tabela americana (diferenças de 26,5, 49 e 25\% dos valores americanos, respectivamente) para carne de gado. A carne de frango apresenta perfil de ácidos graxos mais favorável para a redução dos niveis de colesterol séricos do que a carne de gado. Além disto, as diferenças observadas 
entre nossos dados e os descritos na tabela americana reforçam a importância da construção de tabelas de composição de alimentos regionais.

UNITERMOS: Carne de frango. Ácidos graxos. Poliinsaturados. Saturados. Ácido linolênico. Carne de gado.

\section{REFERENCES}

ALBINO, L.F.T.; NEME, R. Inter-relação ambiência versus nutrição em frangos de corte. In: SIMPÓSIO DE NUTRIÇÃO ANIMAL EM TECNOLOGIA DE PRODUÇÃO, Campinas, Anais. p.65-75, 1998.

BADIANI, A.; STIPA, S.; BITOSSI, F.P.P.; GATTA, V.G.; CHIZZOLINI, R. Lipid composition, retention and oxidation in fresh and completely trimmed beef muscles as affected by common culinary practices. Meat Sci., v. 60, p.169-186, 2002.

BOHAC, C.E.; RHEE, K.S.; CROSS, H.R.; ONO, K. Assessment of methodologies for colorimetric cholesterol assay of meats. J. Food Sci., v. 53, p.1642-1644, 1988.

BRAGAGNOLO, N. Fatores que influenciam o nivel de colesterol, lipídios totais e composição de ácidos graxos em camarão e carne. Campinas, 1997. [Tese de Doutorado. Faculdade de Engenharia de Alimentos. Universidade Estadual de Campinas].

BRAGAGNOLO, N.; RODRIGUEZ-AMAYA, D.B. Total lipid, cholesterol, and fatty acids of farmed freshwater prawn (macrobrachium rosenbergii) and wild marine shrimp (penaeus brasiliensis, penaeus schimitti, xiphopenaeus kroyeri). J. Food Comp. Anal., v. 14, p.359-369, 2001.

CUNIFF, P. In: AOAC INTERNATIONAL. Official methods of analysis of AOAC international. $16^{\text {th }}$ ed. Maryland: AOAC, 1997. vol. II, p. 1, 5-6.

ENSER, M.; HALLETT, K.; HEWETT, B.; FURSEY, G.A.J.; WOOD, J.D.; HARRINGTON, G. Fatty acid content and composition of UK beef and lamb muscle relation to production system and implications for human nutrition. Meat Sci., v. 49, p.329-341, 1998.

FOLCH, J.; LEES, M.; SLOANE-STANLEY, G.H. A simple method for the isolation and purification of total lipids from animal tissues. J. Biol. Chem., v. 226, p.497-509, 1957.
GROSS, J.L.; ZELMANOVITZ, T.; MOULIN, C.C.; DE MELLO, V.; PERASSOLO, M.; LEITAO, C.; HOEFEL, A.; PAGGI, A.; AZEVEDO, M.J., Effect of a chickenbased diet on renal function and lipid profile in patients with type 2 diabetes. D. Care, v. 25, p.645-651, 2002.

HEINTZE, D.; KLENSIN, J.C.; RAND, W.M. International directory of food composition tables. 2nd ed. Cambridge: International Network of Food Data Systems, 1988. $101 \mathrm{p}$.

HOLLAND, B. In: WELCH, A.A.; UNWIN, I.D.; BUSS, D.H.; PAUL, A.A.; SOUTHGATE, D.A.T. (Eds.), McCance and Widdowson's: The composition of foods. London: The Royal Society of Chemistry, Cambridge: Ministry of Agriculture, Fisheries and Food, 1998. p.8-9.

HOPKINS PN. Effects of dietary cholesterol on serum cholesterol: a meta-analysis and review. Am. J. Clin. Nutr., v. 55, p.1060-1070, 1992.

HUTCHISON, G.I.; THOMAS, D.E.; TRUSWELL, A.S. Nutrient composition of australian chicken. Food Tech. Aust., v. 39, p.196-198, 1987.

JOSEPH, J.; ACKMAN, R.G. Capillary column gas chromatographic method for analysis of encapsulated fish oils and fish oil ethyl esters: collaborative study. $J$. AOAC Int., v. 75, p. 488-586, 1992.

JONES P.J. Regulation of cholesterol biosynthesis by diet in humans. Am. J. Clin. Nut., v. 66, p.438-446, 1997.

KARKALAS, J.; DONALD, A.E.; CLEGG, K.M. Cholesterol content of poultry meat and cheese determined by enzymatic and gas-liquid chromatography methods. J. Food Technol., v. 17, p.281-283, 1982.

LEOSDOTTIR, M.; NILSSON, P.M.; NILSSON, J.A.; MANSSON, H.; BERGLUND, G. Dietary fat intake and early mortality patterns - data from The Malmo Diet and Cancer Study. J. Intern. Med., v. 258, n. 2, p. 153-165, 2005.

MOULIN, C.C.; TISKIEVICZ, F.; ZELMANOVITZ, T.; OLIVEIRA, J.; AZEVEDO, M.J.; GROSS, J.L. Use of weighed diet records in the evaluation of diets with different protein contents in patients with type 2 diabetes. Am. J. Clin. Nut., v. 67, p. 853-857, 1998. 
POSATI, L.P. The composition of foods: poultry products. Washington, D.C.: Consumer Food Econ. Inst., 1979. Agricultural Handbook No. 8. Revised August. 330 p.

RAND, W.M.; PENNINGTON, J.A.T.; MURPHY, S.P., KLENSIN, J.C. Compiling Data for Food Composition Data Bases. The United Nations University, 1991. Disponível em: < http://www.unu.edu/unupress/ unupbooks/80772e/80772E00.htm>. Acesso em: 16/07/ 2005 .

RIFAI, N. Measurement of cholesterol concentration. In: WARNICK, G.R.; DOMINICZAK, M.H. (Eds.). Handbook of Lipoprotein Testing. Washington: AACC Press, 1997. p.106-108.

SAVELL, J.W.; HARRIS, J.J.; CROSS, H.R.; HALE, D.S., BEASLEY, L.C. National beef market basket survey. $J$. An. Sci., v. 69, p.2883-2893, 1991.

SCHAEFER E.J. Lipoproteins, nutrition and heart disease. Am. J. Clin. Nut., v. 75, p.191-212, 2002.

STEWART, G., GOSSELIN, C., PANDIAN, S. Selected ion monitoring of tert-butyldimethylsilyl cholesterol ethers for determination of total cholesterol content in foods. Food Chem., v. 44, p.377-380, 1992.

Tabela Brasileira de Composição de Alimentos, Departamento de Alimentos e Nutrição Experimental da Faculdade de Ciências Farmacêuticas - USP e BRASILFOODS (Rede Brasileira de Dados de Composição de Alimentos). Available at $<$ http:// www.fcf.usp.br/tabela/> Acessed in: June, 2005.
Tabela brasileira de composição de alimentos, Núcleo de Estudos e Pesquisas em Alimentação (NEPA), Campinas: UNICAMP, 2004. 42p.

TABER, L.; CHIU, C.; WHELAN, J. Assessment of the arachidonic acid content in foods commonly consumed in american diet. Lipids, v. 33, p.1151-1157, 1998.

U.S. DEPARTMENT OF AGRICULTURE, Agricultural Research Service (2001) USDA nutrient database for standard reference, release 14, nutrient data laboratory, Available at: $<$ http://www.nal.usda.gov/fnic/foodcomp $>$ Accessed in: December 2002.

U.S. DEPARTMENT OF AGRICULTURE. Agricultural Research Service. Composition of foods: beef products, raw, processed, prepared. Agricultural Handbook, Washington DC.: U.S. Government Printing Office, 1990, No. 8-13, p.6.

VIZCARRONDO, C.A., PADILHA, F.C., MARTÍN, E.G. Fatty acid composition of beef, pork and poultry fresh cuts and some of their processed products. Arch. Latioam. Nut. v. 48, p.354-358, 1988.

WAHRMUND-WYLE, J.L., HARRIS, K.B., SAVELL, J.W. Beef retail cut composition: 2. proximate analysis. $J$. Food Comp. Anal., v. 13, p.243-251, 2000.

Recebido para publicação em 29 de março de 2005. Aceito para publicação em 05 de janeiro de 2006. 